\title{
The Effects of Experiential Marketing and Social Media Marketing on Repurchase Intention with Brand Trust as Variable Mediation for Wearing Klamby Hijab Fashion Products
}

\author{
Anis Khoirunnisa and Rina Astini
}

\section{ABSTRACT}

\begin{abstract}
The development and advancement of internet technology have been largely viewed as a very lucrative business opportunity by some. Hijab fashion products are one of the businesses that are currently thriving in their use of social media. In Indonesia, the growth of Wearing Klamby products is beginning, and there is an interesting phenomenon where the brand's products always sell out quickly when a new product series is launched. The purpose of this study was to ascertain the factors influencing repurchase intention and brand trust for Wearing Klamby hijab fashion products. The research is quantitative in nature and includes cross-sectional research. The population for this study consisted of all customers of Wearing Klamby fashion who had made at least two purchases of Wearing Klamby products. The probability sampling method combined with a simple random sampling technique will be used in this study to obtain 155 respondents. The findings of this study indicate that experiential marketing, social media marketing, and brand trust all have a positive and significant effect on repurchase intention. Experiential marketing and social media marketing have a positive and significant effect on brand trust to a lesser extent. In this study, brand trust as a mediating variable had a positive and significant effect on repurchase intention.
\end{abstract}

Keywords: Brand Trust, Experiential Marketing, Repurchase Intention, Social Media Marketing.

\section{INTRODUCTION}

Along with the rapid development of technology in the current era of globalization, it is increasingly easier for people to live life. One of the things that make it easier for the community is the fulfillment of community needs, namely by utilizing online services. The phenomenon of using the internet is an interesting fact, as well as evidence that this media is indeed increasingly loved by the public. The fact is that everyone in this day and age may not be separated from the online media. Everyone can use it to carry out various interests, whether it's for work or even business. In doing business, online media does have the benefit of being more efficient, when compared to conventional marketing methods. Sellers can carry out various forms of marketing activities such as promotions in various online media to attract people's purchasing power to buy the products offered. The high development of the current use of technology by the Indonesian people can be seen from the growth in the use of the internet and social media in 2017-2020 as shown in the following figure.

Promotional offers made by sellers through online media will have an impact on more people knowing about the product. So, it indirectly makes it easier for consumers, so they don't have to spend time visiting stores.
Submitted : October 19, 2021

Published : November 14, 2021

ISSN: $2507-1076$

DOI: $10.24018 /$ ejbmr.2021.6.6.1145

\section{Anis Khoirunnisa*}

Mercu Buana University, Indonesia.

(e-mail: anissula16@ ${ }^{@}$ gmail.com)

Rina Astini

Mercu Buana University, Indonesia.

(e-mail: rina.mgtlearn@ gmail.com)

*Corresponding Author

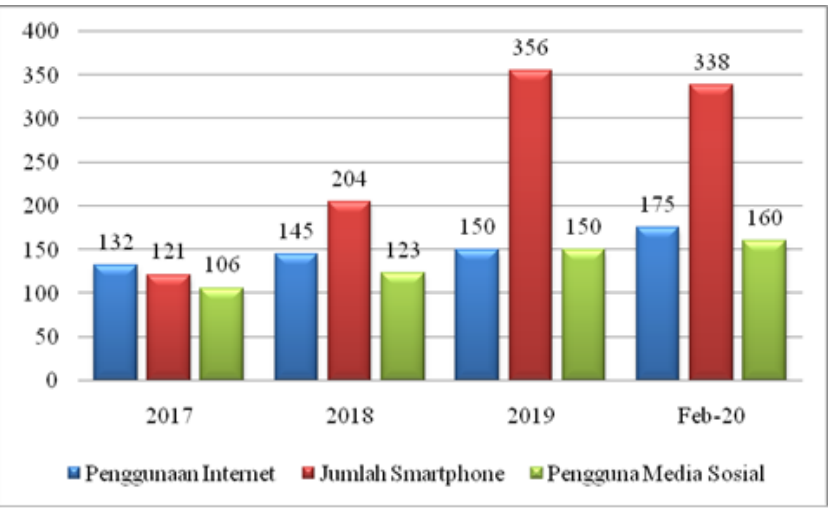

Fig. 1. Growth in Internet and Social Media Use in Indonesia in 2017 2020 (expressed in million people).

Based on the picture above, it can be explained that internet users reach 175 million people. And the number of connected smartphones has reached 338 million units, almost double the number of internet users. This means that on average Indonesians have more than one smartphone. The number of social media users reaches 160 million people. There is an increase of 25 million people or an increase of $17 \%$ from January 2019 to January 2020.

The development and advancement of internet technology have significantly been utilized by some people as a very promising business opportunity. It is proven at this time that 
internet technology has encouraged the formation of various new businesses, especially in the online shopping business, besides that there has also been a significant increase in the number of online shopping sites (Akroush \& Al-Debei, 2015). Based on the analysis of the 2020 E-commerce statistical data, according to the Central Statistics Agency, there has been a drastic increase in online shopping behavior from Indonesian e-commerce throughout 2018 and 2019. This shows a shift in habits from regular store shopping to shopping from online stores. This is helped by many influencing factors such as smartphones, internet data packages, and increasingly affordable access.

Of course, this is an opportunity for brands, because, through this digital media, it is easier for them to find their potential buyers. One of the businesses that are currently booming in utilizing the role of social media is hijab fashion products. Where the style of women's clothing in wearing the hijab is now not only an obligation as a Muslim woman to cover her genitals but has also become a global fashion trend. The potential of the hijab business is very promising with very bright prospects. From the past until now the growth of the hijab business shows a change in the numbers that are increasing significantly. Moreover, Indonesia is a Muslimmajority country which makes this hijab business very prospective. The development of the hijab business has become an interesting phenomenon to be studied, especially in its development in Indonesia.

The hectic competition in the retail industry, especially in the world of hijab fashion, which is mushrooming, of course, must be supported by the right strategy to attract consumers to make purchases of products or services issued by the company. The strategy carried out must also increase the intensity to make repeat purchases (repurchase intention).
Repurchase intention from customers is the most important goal for the company's success to survive amid intense competition with manufacturers of similar products. Repurchase is an attitude of consumer behavior that only buys a product/service repeatedly without including the aspect of liking in it, to create consumer loyalty which is a commitment to a particular brand or product, store, supplier, or company based on a positive attitude reflected in consistent repeat purchases.

The fashion and fashion business are timeless businesses and tend to continue to grow. Fashion has become a very important part of human life and civilization. Several things should be taken into consideration for those who want to start a fashion business, such as determining sales targets and marketing of fashion products to be produced. Sales and marketing targets are very important in this business because they determine the type and model of the product to be marketed. Producing fashion haphazardly without paying attention to who will buy the product will be a big problem in the future because producers will have difficulty marketing their products. Because fashion has become a necessity, producers must be able to understand the wants and needs of consumers for fashion products. Producers must understand consumer behavior so that their products can be absorbed by the market.

One of the hijab fashion products that attracts researchers is the hijab fashion product Wearing Klamby. Wearing Klamby is very active in utilizing digital marketing, especially through social media marketing where social media marketing is currently a very effective means of increasing promotion. We can see the growth data for wearing Klamby products in Indonesia in the table below:

TABLE I: WEARING KLAMBY PRODUCT SALES GROWTH

\begin{tabular}{ccccccc}
\hline \hline & \multicolumn{5}{c}{ Total Product Wearing Klamby (Pcs) } \\
\hline Type of Product & 2014 & 2015 & 2016 & 2017 & 2018 & 2019 \\
\hline Dress & 17,880 & 18.35 & 20,215 & 24,500 & 36,000 & 37,000 \\
blouse & 18.110 & 20,415 & 25,445 & 28,980 & 30,450 & 40,500 \\
Pants & 5.418 & 6.52 & 8,725 & 9,450 & 11,490 & 19,500 \\
Veil & 4.320 & 6,715 & 7.450 & 10.370 & 12,560 & 30,000 \\
Total & $\mathbf{4 5 , 7 2 8}$ & $\mathbf{5 2 , 0 0 0}$ & $\mathbf{6 1 . 8 3 5}$ & $\mathbf{7 3 , 3 0 0}$ & $\mathbf{9 0 , 5 0 0}$ & $\mathbf{1 2 6 , 7 0 0}$ \\
Growth & & $\mathbf{1 4 \%}$ & $\mathbf{1 9 \%}$ & $\mathbf{1 9 \%}$ & $\mathbf{2 3 \%}$ & $\mathbf{4 0 \%}$ \\
\hline \hline
\end{tabular}

Source: Company data processed by researchers, 2020.

The table above shows that sales of wearing Klamby products have continued to increase for 5 years since products were established. The researcher also conducted an exclusive interview with Klamby's manager, Muh. Ridho Jufri, who stated that a significant increase in the quantity of products sold occurred from 2018 to 2019 , which was $40 \%$, and also in 2019 at the beginning of the covid 19 pandemic which occurred where many companies almost went out of business. Survive amid a general economic downturn with steady results showing an increase in product sales by $10 \%$ from 2019 to 2020. Seeing the phenomenon of sales which has increased quite significantly, and along with the increase in the age of the company and the increase in sales of wearing Klamby products every year, then It is very interesting to know the Product Life Cycle, which is a graph that depicts the history of the product since it was introduced to the market until it was withdrawn from the market.
There is an interesting phenomenon that researchers want to examine that something happened to the online hijab fashion shop during the increasingly fierce competition for Muslim clothing, Wearing Klamby with product quality in every detail of the series where the products in the brand always run out in seconds, namely, when the series the product is launched on the day, date and time that has been determined, even though the product is launched at a higher price, the product can always be sold out, and it is very often the website is 'down' during the product check out process due to a large number of customers. to fight for the product even with a very close product launch time.

One of the factors that play an important role that influences consumer decisions in making purchases on online businesses is the quality of service in the online media itself or often referred to as e-service quality. If the service in the resulting online transaction is good, the consumer will feel satisfied and will repurchase intention. 
TABLE II: PRICE LIST OF KLAMBY WEARING SERIES

\begin{tabular}{|c|c|c|c|}
\hline $\begin{array}{l}\text { Type of } \\
\text { Product }\end{array}$ & $\begin{array}{l}\text { Series type/ } \\
\text { Price }\end{array}$ & $\begin{array}{l}\text { Series type/ } \\
\text { Price }\end{array}$ & $\begin{array}{l}\text { Series type/ } \\
\text { Price }\end{array}$ \\
\hline Dress & Rinjani dress plain series/ 295.000 & $\begin{array}{l}\text { Maumere dress Sumba series / } \\
450.000\end{array}$ & $\begin{array}{l}\text { Anggrek dress Harum series/ } \\
475.000\end{array}$ \\
\hline Tunik & Kala Tunik/225.000 & $\begin{array}{l}\text { Derawan Tunik kepulauan series/ } \\
375.000\end{array}$ & $\begin{array}{l}\text { Pinisi Tunik Sulawesi series } \\
1385.000\end{array}$ \\
\hline Blouse & Caludia blouse plain series/ 195.000 & Gardenia blouse plain series/ 265.000 & $\begin{array}{l}\text { Victorian Blouse Palin series/ } \\
375.000\end{array}$ \\
\hline Hijab & Edelweiss scarf nusa tenggara series/200.000 & Anggrek scarf harum series/ 225.000 & Pinisi scarf sulwesi series/ 235.000 \\
\hline Outer & Catalina outer/ 180.0000 & Lalika Outer/195.000 & Rachel outer/350.000 \\
\hline Piyama & Andaleh piyama gadang series/395.000 & Mbaruniang piyama series/395.000 & $\begin{array}{l}\text { Kamboja piyama bali series/ } \\
395.000\end{array}$ \\
\hline Prayer set & Minor Bali prayet mat 165.000 & $\begin{array}{l}\text { Bali Prayet mat in crystal blue/ } \\
185.000\end{array}$ & $\begin{array}{l}\text { Andaleh prayer set gadang } \\
\text { series/495.000 }\end{array}$ \\
\hline
\end{tabular}

In the transaction process, social media marketing is a medium in terms of exchanging information and offering products from a company. Consumers also make the brand one of the important considerations when they want to buy a product. Trust in the brand is one of the factors to improve the relationship with a brand and can be used to create a relationship with consumers in the future (Kim \& Ko, 2010). Brand trust is a very important thing that needs to be maintained and always built because it will have a direct impact on repurchase interest (Dharmayana \& Rahanatha, 2017).

In this study, brand trust is used as a mediating variable. This is because the presence of brands in social networks is very functional in terms of providing information to customers, familiarity, and brand awareness. After all, they are the ones who overcome the limitations of time and space (Seo \& Park, 2018). The use of social media is a new tool because this marketing strategy has the potential to launch a company goal, namely by creating a brand trust (As' ad \& Alhadid, 2014). Thus, with the trust in a brand through social media, it can indirectly affect repurchase interest in a product. According to Rafael's research, brand trust positively affects repurchase intention (David, 2017). Brand trust and repurchase intention are also inextricably linked to the influence of social media, which is extremely useful for providing information to customers, familiarity, and brand awareness, as it is the only medium that transcends time and space constraints. According to the foregoing, the researchers are interested in examining the role of brand trust as a mediating variable in the effect of experiential marketing and social media marketing on repurchase intention for Wearing Klamby products (Aji et al., 2020).

\section{LITERATURE REVIEW AND HYPOTHESES DEVELOPMENT}

\section{A. Consumer Behavior}

Consumer behavior is a process that is closely related to the existence of a buying process, at that time consumers carry out activities such as searching, researching, and evaluating products and services (Firmansyah, 2019). Furthermore, consumer behavior is the thing that underlies and make consumers make purchasing decisions. When deciding to buy an item or product or service, of course, as a consumer, you always think about the goods to be purchased first. Starting from the price, model, shape, packaging, quality, function or use of the item and so on. Basically, according to Firmansyah consumer behavior is generally divided into two, namely rational and irrational consumer behavior (Firmansyah, 2019). Rational consumer behavior is an act of consumer behavior in purchasing goods and services that prioritizes consumer aspects in general, such as the level of urgent need, primary needs, and the benefits of the product itself to the consumer. Meanwhile, irrational consumer behavior is a consumer behavior that is easily persuaded by marketing appeals from a product without prioritizing aspects of needs or interests. In terms of studying consumer behavior, and understanding related to consumer behavior is needed and this is not an easy thing to do because there are so many factors that influence and individual interactions occur between one another, so the concept of a marketing approach must be well designed by consumers. a company and pay attention to these factors.

\section{B. Theory of Planned Behaviour}

The Theory of Planned Behavior is based on the assumption that humans are rational beings and use the information that is possible for them, systematically. People think about the implications of their actions before they decide whether or not to perform certain behaviors. The essence of TPB is the individual's intention to perform certain behaviors wherein TPB subjective attitudes and norms towards behavior are stated to affect interest and include elements of controlling behavioral perceptions as additional factors that influence behavior as factors that influence consumer interest. According to TPB, individual actions on certain behaviors are determined by the individual's interest in carrying out the behavior (Arthana, \& Rukhviyanti, 2017). Giantari et al. (2013) explain that perceived behavior control (PBC) is a belief regarding access to resources and opportunities needed to behave. Then, the measurement of perceived behavioral control is the perception of resources, knowledge, and ability to perform the behavior. Behavioral control is further broken down into control beliefs and perceived power to control behavior. Control beliefs are beliefs about resources and opportunities that can be part of a person's previous experience with the behavior or can be influenced by previous information that increases or reduces the perceived difficulty of performing certain behaviors (Giantari et al., 2013). Perceived power to control behavior is a certain control power to facilitate or hinder the performance of the behavior.

\section{Repurchase Intention}

Fishbein and Ajzen argue that intention (interest) is a strategy because it is likely that someone will behave in a certain way in a given situation regardless of whether they act 
or not (Fishbein \& Ajzen, 1977). Additionally, various research findings indicate that the more a consumer is interested in repurchasing a product, the more they desire to make a purchase and the more they desire a long-term relationship with the company.

\section{Experiential Marketing}

According to Subawa et al. (2020), experiential marketing is the process of identifying and satisfying consumer needs and tantalizing aspirations through two-way communication that reflects the brand personality and adds value to the target audience or customers. Experiential Marketing is used in a variety of situations, according to Schmitt and Roger, including the following (Anaya-Sánchez et al., 2020):

1. Restoring a dwindling company brand.

2. Creating an environment that encourages innovation, purchases, and consumer loyalty.

3. Establishing a distinct market niche for products in a competitive marketplace.

4. Establishing the company's image and identity.

\section{E. Social Media Marketing}

According to Subawa et al. (2020), social media marketing is a process that encourages individuals to communicate product promotions through websites, through online social channels, by leveraging a much larger community than through traditional advertising channels. Social media marketing according to Tong and Subagio has several dimensions, namely as follows: Online Communities, Interaction, Sharing of content, Accessibility, and Credibility (Tong, 2020).

\section{F. Brand Trust}

According to Subawa et al. (2020), consumers use brand trust to guide their purchasing decisions. Consumer trust in a brand can help alleviate uncertainty by assuming that what is chosen is the best and hoping that it lives up to expectations. Additionally, the study explains that customer trust in a product's brand can be defined as a customer's desire to determine and rely on a brand despite the inherent risks.

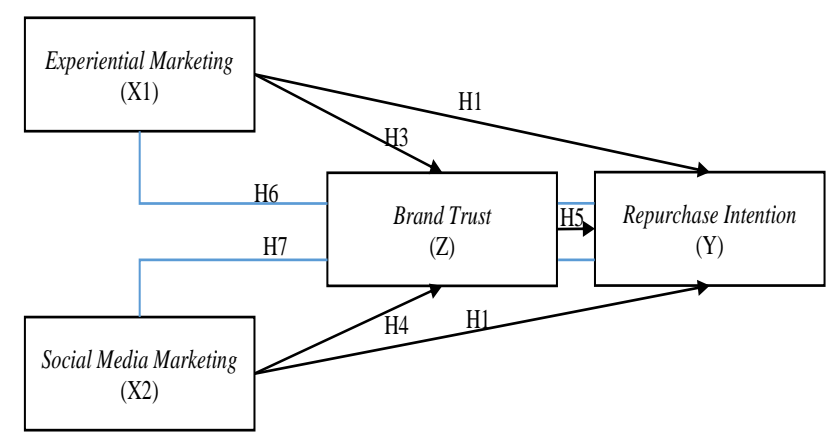

Fig. 2. Conceptual Framework.

Hypothesis:

H1: Experiential Marketing has an effect on Repurchase Intention.

H2: Social Media Marketing has an effect on Repurchase Intention.

H3: Experiential Marketing has an effect on Brand Trust.

H4: Social Media Marketing Affects Brand Trust.
H5: Brand Trust has an effect on Repurchase Intention.

H6: Brand Trust mediates the effect of Experiential Marketing on Repurchase Intention.

H7: Brand Trust mediates the effect of social media marketing on repurchase intention.

\section{RESEARCH METHODS}

The type of approach used in this research is descriptive quantitative. The independent variables in this study are experiential marketing and social media marketing, and the dependent variable is repurchase intention with brand trust as a mediating variable. Furthermore, because the data were collected at one time and only once by distributing questionnaires to the respondents, this study is a crosssectional study. The process of this research begins with the search, collection, processing, and writing of the results of the report to the presentation of the results as a whole. In this whole process, it will take time from September 2020 until the trial is finished.

The population in this study were all customers of hijab wearing Klamby fashion who had purchased Klamby wearing products more than 2 times. The samples in this study were individuals who had purchased Klamby wearing products more than 2 times which had the characteristics required in the study and could be used as respondents. The research sampling method that will be used in this study is the probability sampling method with the simple random sampling technique. Determination of the number of representative samples according to Hair is dependent on the number of indicators multiplied by 5 or 10 (Hair et al., 2017). Based on the number of indicators $(5 \times 31=155)$ and $(10 \times 31$ =310). In this study, researchers took 155 respondents.

This study uses a Structural Equation Model (SEM) approach with a measurement model using the Smart PLS version 3.2.9 program to measure the intensity of each research variable and a structural model to analyze the data and research hypotheses.

\section{FINDING AND Discussion}

\section{A. Evaluation of the Measurement Model (Outer Model)}

The evaluation of the measurement model (outer model) is carried out to specify the relationship between the indicators and their latent variables. Therefore, the evaluation of this outer model defines how each indicator relates to its latent variable. The results of the analysis are used to ensure that the measurement results used are suitable for measurement (valid and reliable). The results of the outer reflective model analysis can be seen from several indicators (Table III).

It is known that based on the table shows that the correlation values of experiential marketing, social media marketing, brand trust, and repurchase intention constructs with their indicators are greater than the correlation values with other constructs. Thus, it can be concluded that all latent constructs of each variable show good discriminant validity because they can predict indicators on the cross-loading value. 
TABLE III: CROSS LOADING VALUE

\begin{tabular}{|c|c|c|c|c|}
\hline & $\begin{array}{c}\text { Experiential } \\
\text { Marketing }\end{array}$ & $\begin{array}{l}\text { Social Media } \\
\text { Marketing }\end{array}$ & $\begin{array}{l}\text { Brand } \\
\text { Trust }\end{array}$ & $\begin{array}{l}\text { Repurchase } \\
\text { Intention }\end{array}$ \\
\hline EM1 & 0,875 & 0,502 & 0,589 & 0,595 \\
\hline EM2 & 0,756 & 0,482 & 0,537 & 0,500 \\
\hline EM3 & 0,846 & 0,478 & 0,572 & 0,597 \\
\hline EM4 & 0,784 & 0,427 & 0,484 & 0,464 \\
\hline EM5 & 0,772 & 0,490 & 0,551 & 0,578 \\
\hline EM6 & 0,772 & 0,381 & 0,453 & 0,416 \\
\hline EM7 & 0,859 & 0,570 & 0,614 & 0,628 \\
\hline EM8 & 0,796 & 0,497 & 0,595 & 0,534 \\
\hline EM9 & 0,789 & 0,502 & 0,591 & 0,568 \\
\hline EM10 & 0,723 & 0,405 & 0,493 & 0,430 \\
\hline EM11 & 0,763 & 0,436 & 0,578 & 0,491 \\
\hline EM12 & 0,805 & 0,438 & 0,535 & 0,535 \\
\hline SCM1 & 0,404 & 0,749 & 0,501 & 0,415 \\
\hline SCM2 & 0,286 & 0,744 & 0,410 & 0,433 \\
\hline SCM3 & 0,626 & 0,756 & 0,584 & 0,607 \\
\hline SCM4 & 0,497 & 0,735 & 0,518 & 0,471 \\
\hline SCM5 & 0,467 & 0,844 & 0,613 & 0,564 \\
\hline SCM6 & 0,349 & 0,723 & 0,426 & 0,397 \\
\hline SCM7 & 0,452 & 0,799 & 0,502 & 0,463 \\
\hline SCM8 & 0,493 & 0,785 & 0,492 & 0,490 \\
\hline SCM9 & 0,461 & $\mathbf{0 , 8 0 7}$ & 0,496 & 0,522 \\
\hline BTR1 & 0,622 & 0,579 & 0,905 & 0,664 \\
\hline BTR2 & 0,552 & 0,514 & 0,826 & 0,634 \\
\hline BTR3 & 0,550 & 0,638 & 0,826 & 0,596 \\
\hline BTR4 & 0,594 & 0,565 & 0,843 & 0,605 \\
\hline BTR5 & 0,561 & 0,534 & $\mathbf{0 , 8 4 7}$ & 0,627 \\
\hline BTR6 & 0,642 & 0,529 & $\mathbf{0 , 8 3 0}$ & 0,613 \\
\hline REI1 & 0,561 & 0,560 & 0,622 & $\mathbf{0 , 8 8 2}$ \\
\hline REI2 & 0,596 & 0,512 & 0,644 & $\mathbf{0 , 8 2 2}$ \\
\hline REI3 & 0,494 & 0,516 & 0,607 & $\mathbf{0 , 8 5 0}$ \\
\hline REI4 & 0,629 & 0,582 & 0,641 & $\mathbf{0 , 8 6 3}$ \\
\hline
\end{tabular}

TABLE IV: AVE (AVERAGE VARIANCE EXTRACTION) RESUlTS FROM THE

\begin{tabular}{lc}
\multicolumn{2}{c}{ RESEARCH MODEL } \\
\hline \hline \multicolumn{1}{c}{ Variable } & AVE Value \\
\hline Experiential Marketing & 0,634 \\
Social Media Marketing & 0,596 \\
Brand Trust & 0,717 \\
Repurchase Intention & 0,730 \\
\hline \hline
\end{tabular}

The AVE value of the research model for the experiential marketing, social media marketing, brand trust, and repurchase intention variables has been valued above 0.5 so that the AVE value for discriminant validity testing has been met for further testing. Thus, the discriminant validity test has been fulfilled as well as the convergent validity test.

TABLE V: COMPOSITE RELIABILITY RESULTS FROM RESEARCH MODEL

\begin{tabular}{lc}
\multicolumn{1}{c}{ Variable } & Composite \\
& Reliability \\
\hline Experiential Marketing & 0,954 \\
Social Media Marketing & 0,930 \\
Brand Trust & 0,938 \\
Repurchase Intention & 0,915 \\
\hline \hline
\end{tabular}

The composite reliability value from the research model shows that each variable has a composite reliability value above 0.7 with the lowest value of 0.915 from the repurchase intention variable and the highest value of 0.954 from the experiential marketing variable. From these results, it can be concluded that the research model has met the value of composite reliability. As well as social media marketing variable and brand trust variable.

The Cronbach's alpha value from the research model shows that each variable has a Cronbach's alpha value above 0.6 with the lowest value of 0.877 from the repurchase intention variable (Y) and the highest value of 0.947 from the experiential marketing variable (X1). As well as social media marketing variable and brand trust variable.

From these results, it can be concluded that the research model has met the value of Cronbach's alpha.

TABLE VI: CRONBACH'S ALPHA RESUlTS FROM THE RESEARCH MODEL

\begin{tabular}{lc}
\hline \multicolumn{1}{c}{ Variable } & Composite \\
& Reliability \\
\hline Experiential Marketing $(X 1)$ & 0,947 \\
Social Media Marketing $(X 2)$ & 0,915 \\
Brand Trust $(Z)$ & 0,921 \\
Repurchase Intention $(Y)$ & 0,877 \\
\hline \hline
\end{tabular}

\section{B. Structural Model Testing (Inner Model)}

This model is a specification of the relationship between latent variables, also known as the inner model. This test is a test of the type and magnitude of the influence of the independent latent variable on the dependent latent variable.

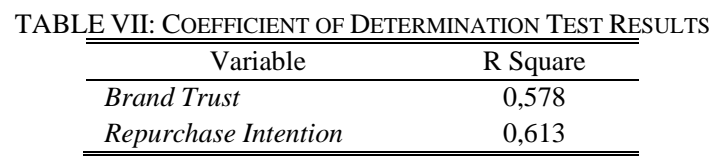

The R-square value of the brand trust variable is 0.578 , this indicates that $57.8 \%$ of the brand trust variable can be influenced by experiential marketing and social media marketing variables. Then the R-square value of the repurchase intention variable is 0.613 , this shows that $61.3 \%$ of the repurchase intention variable can be influenced by experiential marketing, social media marketing, and brand trust variables.

The results of the research model are described as follows:

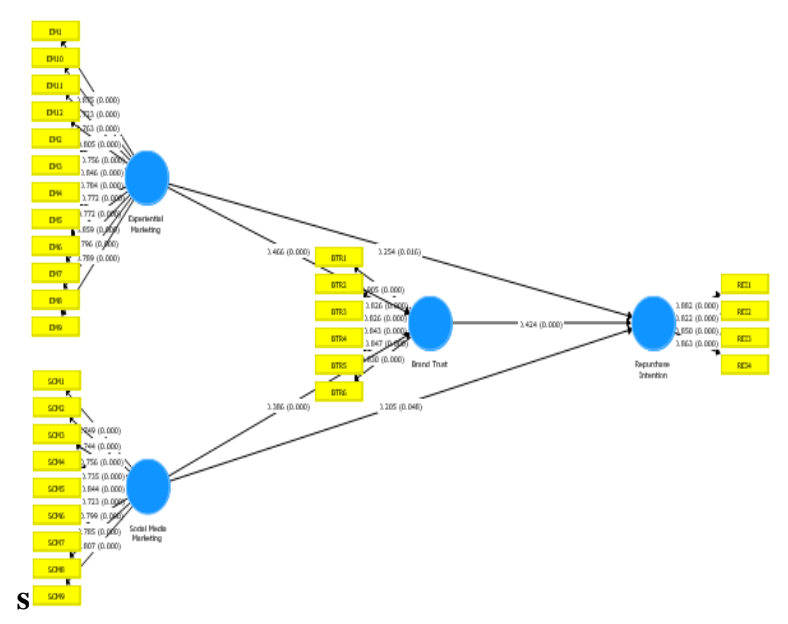

Fig. 3. Research Path Diagram.

From Fig. 3 and Table VIII, it is known that the experiential marketing variable on repurchase intention has a path coefficient value of +0.254 with a t-count value of $2.419>1.96$ and a p-value of $0.016<0.05$. Thus, experiential marketing has a positive and significant effect on repurchase intention. This indicates that someone will be willing to make repeat purchases because these consumers have experienced, felt, and provided experiences for them by buying products that match their wants and needs as consumers. Thus, the higher the consumer's experiential marketing, the higher the consumer's repurchase interest in hijab-wearing Klamby fashion products. 
TABLE VIII: RESULTS OF PATH COEFFICIENT, T-STATISTICS, AND P-

\begin{tabular}{|c|c|c|c|c|}
\hline & $\begin{array}{l}\text { Original } \\
\text { Sample }\end{array}$ & $\begin{array}{c}\mathrm{T} \\
\text { Statistics } \\
\end{array}$ & $\begin{array}{c}\mathrm{P}- \\
\text { values }\end{array}$ & Conclusion \\
\hline $\begin{array}{l}\text { Experiential } \\
\text { Marketing } \rightarrow \\
\text { Repurchase Intention }\end{array}$ & 0,254 & 2,419 & 0,016 & $\begin{array}{c}\mathrm{H} 1 \\
\text { Accepted }\end{array}$ \\
\hline $\begin{array}{l}\text { Social Media } \\
\text { Marketing } \rightarrow \\
\text { Repurchase Intention }\end{array}$ & 0,205 & 1,986 & 0,048 & $\begin{array}{c}\mathrm{H} 2 \\
\text { Accepted }\end{array}$ \\
\hline $\begin{array}{l}\text { Experiential } \\
\text { Marketing } \rightarrow \text { Brand } \\
\text { Trust }\end{array}$ & 0,466 & 4,454 & 0,000 & $\begin{array}{c}\mathrm{H} 3 \\
\text { Accepted }\end{array}$ \\
\hline $\begin{array}{l}\text { Social Media } \\
\text { Marketing } \rightarrow \text { Brand } \\
\text { Trust }\end{array}$ & 0,386 & 4,097 & 0,000 & $\begin{array}{c}\mathrm{H} 4 \\
\text { Accepted }\end{array}$ \\
\hline $\begin{array}{l}\text { Brand Trust } \rightarrow \\
\text { Repurchase Intention }\end{array}$ & 0,424 & 4,179 & 0,000 & $\begin{array}{c}\text { H5 } \\
\text { Accepted }\end{array}$ \\
\hline $\begin{array}{l}\text { Experiential } \\
\text { Marketing } \rightarrow \text { Brand } \\
\text { Trust } \rightarrow \text { Repurchase } \\
\text { Intention }\end{array}$ & 0,198 & 3,392 & 0,001 & $\begin{array}{c}\text { H6 } \\
\text { Accepted }\end{array}$ \\
\hline $\begin{array}{l}\text { Social Marketing } \rightarrow \\
\text { Brand Trust } \rightarrow \\
\text { Repurchase Intention }\end{array}$ & 0,164 & 2,706 & 0,007 & $\begin{array}{c}\mathrm{H} 7 \\
\text { Accepted }\end{array}$ \\
\hline
\end{tabular}

Then the social media marketing variable on repurchase intention has a path coefficient value of +0.205 with a t-count value of $1.986>1.96$ and a p-value of $0.048<0.05$. Thus, social media marketing has a positive and significant effect on repurchase intention. From this, it can be interpreted that consumers will be willing to make repeat purchases because these consumers are interested in various social media activities wearing Klamby, such as interesting content, interaction reviews, or testimonials between loyal customer communities on social media wearing Klamby, as well as various activities carried out by the community. wearing Klamby through social media such as giving away, webinars, and also surprises broadcast through social media. Thus, the higher the consumer's social media marketing, the higher the consumer's repurchase interest in hijab-wearing Klamby fashion products.

From the previous table, it is also known that experiential marketing on brand trust has a path coefficient value of +0.466 with a t-count value of $4.454>1.96$ and a p-value of $0.000<0.05$. Thus, experiential marketing has a positive and significant effect on brand trust. From this it can be interpreted that consumers will be willing to make repeat purchases because these consumers have a sense of trust by experiencing and feeling comfortable with the fulfillment of their desires and needs in buying Klamby hijab fashion products, because the better the brand experience, the level of consumer confidence in the brand will the higher it is. Experiential marketing is a marketing concept that aims to form loyal customers by touching customer emotions by creating positive experiences and giving positive feelings towards services and products.

The results of the hypothesis test also show that the social media marketing variable on brand trust has a path coefficient value of +0.386 with a t-count value of $4.097>1.96$ and a pvalue of $0.000<0.05$. Thus, social media marketing has a positive and significant effect on brand trust. From this, it can be interpreted that consumers will be willing to make repeat purchases because these consumers believe they feel comfortable and feel satisfied with wearing Klamby, because of the trust that customers have in their interactions with brands such as interactions on social media, based on the perception that brands can be trusted and accountable for attracting and satisfying customers.

The brand trust variable on repurchase intention has a path coefficient value of +0.424 with a t-count value of $4.179>$ 1.96 and a p-value of $0.000<0.05$. Thus, brand trust has a positive and significant effect on repurchase intention. From this, it can be interpreted that consumers will be willing to make repeat purchases because these consumers feel the belief that wearing Klamby can fulfill the wishes and expectations of their consumers. Thus, it can be interpreted that the high value of consumer trust also determines the high repurchase intention. Brand trust is a very important thing that needs to be maintained and always built because it will have a direct impact on repurchase interest (Dharmayana \& Rahanatha, 2017). Trust in the brand of a product by consumers, can reduce all risks and uncertainties.

In this study, there is also a mediating variable, namely brand trust, it is known that the variable brand trust mediating experiential marketing on repurchase intention has a path coefficient value of +0.198 with a t-count value of $3.392>$ 1.96 and a p-value of $0.001<0.05$. Thus, experiential marketing has a positive and significant effect on repurchase intention mediated by brand trust. From this, it can be interpreted that consumers believe that with positive feedback from experiential marketing, consumers are willing to make repeat purchases. If someone uses an item over and over again, then it can be said to be experienced in using the item and it can be judged that they trust the item so that the person has the intention to buy the item repeatedly, and vice versa. This means that the better and increased customer trust resulting from the brand experience, the consumers tend to be able to increase their repurchase intentions.

Finally, it is known that the brand trust variable mediating social media marketing on repurchase intention has a path coefficient value of +0.164 with a t value of $2.706>1.96$ and a p-value of $0.007<0.05$. Thus, social media marketing has a positive and significant effect on repurchase intention mediated by brand trust. This means that consumers believe that positive feedback from social media marketing will increase the impact of consumers on creating repurchase intentions. With the existence of a more interactive social media system, the existence of an online community on the brand and various social media activities on the brand itself that attract consumers so that consumers turn to social media to get information on certain products and services, which can also ultimately have an impact on increasing intentions. consumers buy. This means that social media marketing has a significant effect on repurchase intention through brand trust mediation. One of the key requirements for strong customer purchase intentions in the online and social media environment is customer trust. Social media provides live networking, instant feedback, and more real customergenerated content.

\section{CONCLUSION}

Based on the results of the research that has been done, it can be concluded as follows:

1. Experiential marketing has a positive and significant effect on repurchase intention. 
2. Social media marketing has a positive and significant effect on repurchase intention.

3. Experiential marketing has a positive and significant effect on brand trust.

4. Social media marketing has a positive and significant effect on brand trust.

5. Brand trust has a positive and significant effect on repurchase intention.

6. Experiential marketing has a positive and significant effect on repurchase intention mediated by brand trust.

7. Social media marketing has a positive and significant effect on repurchase intention mediated by brand trust.

\section{RECOMMENDATION}

It is recommended to the management to be able to maintain and improve their services so that in the context of experiential marketing, customers have a positive experience with Wearing Klamby, this can be done, among others, by delivering products on time, providing a very fast response to every customer request, and being friendly and polite when serving customers so that customers continue to make repeat purchases. It is also advisable to be more active in carrying out online social media activities for consumers, such as conducting loyal customer gatherings, or by holding online seminars that attract consumers to stay loyal to wearing Klamby's social media. Lastly, management should be able to increase trust by meeting the expectations of their customers' wants and needs, such as giving various quizzes on social media, the purpose of which is to find out what is desired and needed for wearing Klamby products, as well as getting a good response to the quality resulting from the purchase. hijab fashion product Wearing Klamby.

For further research to be able to add other variables that can also determine repurchase intention in Klamby Fashion Hijab Customers, such as service quality, word-of-mouth, brand image, price, and product quality. So that it will be able to know more about the dominant factors that have a wider influence on the formation of trust and repurchase interest in customers. And it is expected to use more samples so that the research results obtained can be more accurate.

\section{REFERENCES}

Aji, P., Nadhila, V., \& Sanny, L. (2020). Effect of social media marketing on Instagram towards purchase intention: Evidence from Indonesia's ready-to-drink tea industry. International Journal of Data and Network Science, 4(2), 91-104.

Akroush, M. N., \& Al-Debei, M. M. (2015). An integrated model of factors affecting consumer attitudes towards online shopping. Business Process Management Journal.

Anaya-Sánchez, R., Aguilar-Illescas, R., Molinillo, S., \& Martínez-López, F. J. (2020). Trust and loyalty in online brand communities Confianza y lealtad en las comunidades online de marca.

Arthana, Y. W., \& Rukhviyanti, N. (2017). Pengaruh Minat Individu Terhadap Penggunaan Mobile Banking (M-Banking): Model Kombinasi Technology Acceptance Model (Tam) Dan Theory Of Planned Benavior (Tpb). Jurnal Informasi, 7(1), 25-44.

As' ad, H. A.-R., \& Alhadid, A. Y. (2014). The impact of social media marketing on brand equity: An empirical study on mobile service providers in Jordan. Review of Integrative Business and Economics Research, 3(1), 315.

David, A. (2017). Aaker On Branding; Branding 20 Prinsip Esensial Mengelola dan Mengembangkan Brand. PT Gramedia Pustaka Utama.
Dharmayana, I. M. A., \& Rahanatha, G. B. (2017). Pengaruh brand equity, brand trust, brand preference, dan kepuasan konsumen terhadap niat membeli kembali [PhD Thesis]. Udayana University.

Firmansyah, M. A. (2019). Perilaku Konsumen (Sikap dan Pemasaran). Penerbit Qiara Media.

Fishbein, M., \& Ajzen, I. (1977). Belief, attitude, intention, and behavior: An introduction to theory and research. Philosophy and Rhetoric, 10(2).

Giantari, I., Zain, D., Rahayu, M., \& Solimun, M. (2013). The role of perceived behavioral control and trust as mediator of experience on online purchasing intentions relationship a study on youths in denpasar city (Indonesia). International Journal of Business and Management Invention, 2(1), 30-38.

Hair, J., Hollingsworth, C. L., Randolph, A. B., \& Chong, A. Y. L. (2017) An updated and expanded assessment of PLS-SEM in information systems research. Industrial Management \& Data Systems, 117(3), $442-458$.

Kim, A. J., \& Ko, E. (2010). Impacts of luxury fashion brand's social media marketing on customer relationship and purchase intention. Journal of Global Fashion Marketing, 1(3), 164-171.

Seo, E.-J., \& Park, J.-W. (2018). A study on the effects of social media marketing activities on brand equity and customer response in the airline industry. Journal of Air Transport Management, 66, 36-41.

Subawa, N. S., Widhiasthini, N. W., \& Suastika, N. P. M. W. S. (2020). The effect of experiential marketing, social media marketing, and brand trust on repurchase intention in Ovo applications. International Research Journal of Management, IT and Social Sciences, 7(3), 11-21.

Tong, T. K. P. B. (2020). Analisa pengaruh social media marketing terhadap repurchase intention melalui brand trust sebagai variabel mediasi pada instagram adidas Indonesia di Surabaya. Jurnal Strategi Pemasaran, $7(1), 10$. 